\section{The Authors' reply}

To the Editor: Freeman and Mansfield find our conclusions on the association between the $-6754 \mathrm{G} / 5 \mathrm{G}$ PAI-1 polymorphism and obesity, recently published [1], to be overstated. This statement is based on their study showing no difference in genotype frequency between lean, overweight or obese subjects [2]. However, several questions arise as to interpreting their results. Firstly, the genotype distribution differed from the Hardy-Weinberg equilibrium, which makes the genotyping doubtful. Secondly, a family-based cohort is suitable for linkage, but not association, studies. Finally, given these shortcomings it should be noted that in the Freeman and Mansfield study, the $4 \mathrm{G} / 4 \mathrm{G}$ genotype was almost twice as common as the $5 \mathrm{G} / 5 \mathrm{G}$ genotype in the overweight and obese groups but there was no difference in the lean group. This is similar to our study [1], where a higher frequency of $4 \mathrm{G} / 4 \mathrm{G}$ and a lower frequency of $5 \mathrm{G} / 5 \mathrm{G}$ in obese as compared to lean subjects were observed. Thus, the difference in results between the two studies resides in the $p$ value, which was statistically significant in our study. We believe that our study is more suitable for interpretation, since it was carried out on non-related case-control subjects.
* P. Arner and J. Hoffstedt wrote this letter on behalf of the coauthors of the original article

P. Arner, J. Hoffstedt

\section{References}

1. Hoffstedt J, Andersson I-L, Persson L, Isaksson B, Arner P (2002) The common -675 4G/5G polymorphism in the plasminogen activator inhibitor-1 gene is strongly associated with obesity. Diabetologia 45: 584-587

2. Freeman MS, Mansfield MW, Barett JH, Grant PJ (2002) Genetic contribution to circulating levels of hemostatic factors in healthy families with effects of known genetic polymorphisms on heritability. Arterioscler Thromb Vasc Biol 22: $506-510$

Corresponding author: P. Arner, MD Department of Medicine, Karolinska Institutet, Huddinge University Hospital, CME, MK Division, Stockholm, Sweden, E-mail: Peter.Arner@medhs.ki.se

Received: 11 July 2002

Published online: 3 October 2002

(C) Springer-Verlag 2002 